УДК $930.85: 7.04: 738.5$

DOI: https://doi.org/10.33782/eminak2020.3(31).448

\title{
ЗОБРАЖЕННЯ БОГОРОДИЦІ У САКРАЛЬНОМУ МИСТЕЦТВІ ТА МУЗЕЙНИХ КОЛЕКЦІЯХ ВЕНЕЦІЇ
}

\author{
Ірина Гнідик \\ Національний університет «Львівська політехніка» (Львів, Україна) \\ e-mail: iryna.i.hnidyk@lpnu.ua \\ ORCID: https://orcid.org/0000-0001-7560-3365
}

На основі італо- й англомовної літератури представлено аналітичний огляд зображень Богородиці у релігійному живописі, скульптурному мистецтві, музейних колекціях $і$ мозаїках м. Венеції. Почитання Пречистої Діви Марії, як покровительки міста, у Венеції має давні історичні витоки й яскраво виражене за допомогою візуальної мови мистецтва різних стилів, зокрема італійського ренесансу. Відомі малярі, представники знаменитої венеційської школи живопису, залишили після себе велику кількість полотен присвячених Богородиці, які зберігаються у храмах, музеях, галереях Венеції та репрезентують важливий вимір для сучасних історичних, мистецьких, теологічних і маріологічних досліджень.

Іншим важливим аспектом є мозаїки храмів Венеції та островів Венеційської лагуни, які представляють переплетення візантійського стилю з творчими здобутками венеційських майстрів, які грунтовно навчалися техніки візантійського мистецтва, у результаті витворивши свої унікальні стилістичні особливості.

Ключові слова: Богородиця, сакральне мистещтво, Венеція, музеї, мозаїки, релігійний живопис, ікона

Італійське мистецтво репрезентує настільки багатий матеріал для дослідників різних напрямків, особливо у міждисциплінарному вимірі, що знаходження малодосліджених аспектів потребує тривалого детального грунтовного вивчення історіографії. Зрештою, мистецьке становлення й особливості окремих міст Італії репрезентують доволі актуальну та широку тематику для сучасної аналітики. У цьому контексті мистецька історія Венеції, своєрідної перлини світової спадщини ЮНЕСКО, що знаходиться під загрозою, ставить перед сучасними науковцями багато актуальних питань. Одним із таких тематичних вимірів, який потребує детальнішого вивчення й аналітики є історичні та мистецькі особливості зображень Богородиці у сакральному мистецтві Венеції на основі полотен, ікон, скульптурних композицій у храмах і музеях міста, а також мозаїках базилік островів Венеційської лагуни.

Характерною особливістю мистецької спадщини Венеції $є$ яскраве переплетення західного та східного стилю, особливо у сакральному мистецтві. Упродовж періоду розквіту Венеційська республіка була потужним політичним, економічним, культурним і мистецьким центром тодішнього європейського простору та своєрідним місцем зустрічі та діалогу західної та східної культури. Для чіткості дослідження необхідно відразу чітко виділити дві окремі групи сакральних зображень Венеції: 1) ікони візантійського стилю, які потрапляли у Венецію з території Візантії або ж з о. Крит, де функціонував потужний на той час іконописний осередок; 2) живописні полотна західного стилю сакрального мистецтва, які яскраво репре- 
зентують ключові етапи розвитку мистецького розвитку Італії та, зокрема, венеційської школи живопису. Очевидно, що кожна група зображень потребує свого окремого дослідження та специфічних методологічних підходів.

3 огляду на такі обставини, метою статті $€$ аналітичне висвітлення культурної спадщини сакрального мистецтва Венеції, а саме - зображень Богородиці, що суттєво й актуально звужує поле дослідження, представляючи маловивчені та перспективні у міждисциплінарному вимірі аспекти. Натомість дослідження відомих і маловідомих венеційських ікон Богородиці справедливо заслуговує на окремі аналітичні роботи та історіографічні огляди, тому у цій статті зазначений тематичний вимір буде згадуватися лише фрагментарно.

Історіографія. Вивчення й аналітика зображень Богородиці у полотнах відомих художників $є$ особливо актуальною тематикою для дослідників як історичного, мистецтвознавчого, так і теологічного аспектів. Зарубіжні дослідники присвятили цій тематиці значну кількість аналітичних праць. На особливу увагу заслуговують праці італійських дослідників. Зокрема, яскравим взірцем є цікава історіографія досліджень зображень Богородиці у творчості Мікеланджело‥ Відповідно, вартує розділити історіографію дослідження сакрального мистецтва Італії та Венеції, зокрема на кілька груп: 1) загальні дослідження тематичних напрямів розвитку релігійного живопису Італії, які принагідно, однак узагальнено, згадують відомі полотна із зображенням Богородиці; 2) праці, присвячені вивченню спадщини сакрального мистецтва саме венеційського живописного осередку у загальному вимірі; 3) розвідки, які розглядають окремо творчість визначних венеційських малярів i, зокрема, зображення Пречистої Діви Марії в їхньому творчому доробку.

Крім цього, важливим історіографічним критерієм $є$ хронологічна класифікація головних періодів мистецького розвитку Італї. До прикладу, дослідник В. Франча проаналізував іконографію Богородиці в італійському живописі періоду ренесансу2. Натомість Т. Вердон, крім комплексних досліджень італійського сакрального мистецтва в історичній ретроспективі ${ }^{3}$, особливу увагу присвятив Богородичній тематиці у праці «Марія в європейському мистецтві»4. Л.Пуппі окремо зупинився на вивченні зображень Богородиці у творчості відомих малярів у Венеції другої половини XVI ст. ${ }^{5}$

3 іншого боку, є також фрагментарні дослідження творчості менш відомих малярів, не завжди італійського походження, поодинокі (а іноді - одиничні) роботи яких, присвячені Богородиці, зберігаються у венеційських музеях 6 . Цікаві case study дослідження щодо окремих іконографічних сюжетів зображення Пречистої Діви Марії в італійському мистецтві7. Крім цього, особливу історіографічну групу становлять старовинні італомовні книги XVIII ст., які детально розглядають істо-

\footnotetext{
1 De Fiores, Stefano. La Madonna in Michelangelo. Libreria Editrice Vaticana, 2010. 239 p.

2 Francia V. Splendore di bellezza. L'iconografia dell'Immacolata Concezione nella pittura rinascimentale italiana. Città del Vaticano, 2004.

3 Verdon Th. L'arte sacra in Italia. L'immaginazione religiosa dal paleocristiano al modern. Milano, 2001.

4 Verdon Th. Maria nell'arte europea. Milano, 2004.

${ }^{5}$ Puppi L. Il Greco giovane e altri pittori «Madonneri» di maniera italiana a Venezia nella seconda metà del Cinquecento // Prospettive. 1963. № 26/27. P. 25-46.

${ }^{6}$ Bianco Fiorin, Marisa. Giovanni Permeniate Pittore greco a Venezia e una tavola del Museo Nazionale di Ravenna // Bollettino d'Arte, Serie 6. Vol. 11. Roma: La libreria dello Stato, 1981. P. 85-88.

7 Salvador-González, José María. The Iconography of the Coronation of the Virgin In Late Medieval Italian Painting. A Case Study // Eikón / Imago 3. 2013. № 1. P. 1-48.
} 
рію відомих венеційських зображень Діви Марії, однак ключова увага у цих розвідках присвячена саме чудотворним іконам Богородиці8.

Таким чином, детальне вивчення зазначеної тематики на основі різних груп джерел і літератури відкриває сучасним дослідникам можливості дослідити маловідомі аспекти.

Почитання Богородиці розвивалося дуже активно у Венеції, свідченням чого $\epsilon$ історичні джерела, велика кількість зображень і наукові дослідження. У старовинних італійських книгах XVIII ст. «Історичні відомості про об'явлення та найвідоміші образи Пресвятої Богородиці у місті та домені Венеції. Взяте з документів, традицій і старовинних книг з церков, де шанують ці зображення» та «Venezia favorita da Maria. Relazione delle imagini miracolose di Maria conservate in Venezia»9 зазначено, що Венеція та її прилеглі території завдячують Богородиці великою кількістю благословень і материнським заступництвом. У цьому контексті автори наголошують, що на території Венеції дуже часто можна зустріти чудотворне зображення Богородиці як знак особливої опіки над містом ${ }^{10}$. На початку першої згаданої книги вміщено цікаву гравюру із зображенням жінки, що є символічною алегорією Венеції, яка стоїть навколішки перед Богородицею з Ісусом на руках, внизу - крилатий лев з книгою, символ апостола Марка - покровителя Венеції11.

Схожий мотив, але у скульптурному виконанні, вміщено у базиліці Madonna di Salute, у головному вівтарі, який обрамлює відому чудотворну ікону Пречистої Діви Марії. Скульптурна група митця Джусто Ле Корт (Giusto Le Court): алегорична жіноча скульптура, що символізує Венецію, яка навколішки дякує Богородиці за порятунок від епідемії у 1631 p.12 (саме на знак подяки за це венеційці побудували цю базиліку на честь Богоматері). Своєрідним доказом того, що у скульптурній групі $\epsilon$ персоніфікація Венеції, $\epsilon$ те, що неподалеку на землі $\epsilon$ головний убір дожів. Богородиця дивиться на неї, рукою ніби огортаючи місто, натомість з протилежного боку ангел з палаючим факелом виганяє алегоричну постать старої жінки, що символізує хворобу. Також ліворуч внизу знаходиться скульптура св. Марка з книгою у руках (про що свідчить зображення лева поблизу), а праворуч - св. Лоренцо Джустініані, першого патріарха Венеції13.

Подібну композицію зображено також у картині венеційського митця Доменіко Тінторетто «Венеція благає Пречисту Діву про заступництво перед Христом з проханням про завершення чуми» 1631 р. (знаходиться у храмі San Francesco della Vigna), де Венеція, персоніфікована у постаті жінки, навколішки звертається до Богородиці; біля цієї жінки - зображення лева з написом «рах» (зазвичай цей напис можна побачити на розгорнутій книзі, яку тримає лев: «Pax tibi Marce evangelista meus», що перекладається як «Мир тобі, Марко, мій євангелисте»). У цьому зображенні напис скорочено до одного слова, але це дає можливість ідентифікувати си-

\footnotetext{
8 Cornaro, Flaminio. Venezia favorita da Maria. Relazione delle imagini miracolose di Maria conservate in Venezia. Giov. Manfre, 1758; Corner, Flaminio. Notizie storiche delle apparizioni, e delle immagini più celebri di Maria Vergine Santissima nella città e dominio di Venezia. Tratte da Documenti, Tradizioni, ed antichi libri delle Chiese nelle quali esse Immagini son venerate. Venezia: Presso Antonio Zatta, 1761. P. 5.

9 Venezia favorita da Maria.

10 Notizie storiche delle apparizioni... P. 5.

11 Ibid. P. 1.

12 Venezia. T. 7. Touring club italiano. Touring Editore, 1985. P. 421.

${ }^{13}$ Santa Maria della Salute a Venezia a cura di Mattio Tridello. URL: https://www.progettostoriadellarte.it/2020/05/26/santa-maria-della-salute-a-venezia/
} 
мвол св. Марка. На задньому фоні на ношах несуть хворих і, очевидно, померлих від епідемії14. До речі, батько художника - Якопо Тінторетто, визначний венеційський маляр біблійних сюжетів, намалював картину у стилі маньєризму «Дож Нікколо да Понте перед Пречистою Дівою у славі» (зберігається у Палаці дожів у Венеції), де зображено подібний сюжет - дож навколішки звертається до Богородиці, очевидно теж у проханні про заступництво над містом (краєвиди якого відтворені на задньому фоні) 15 .

Венеція була потужним мистецьким осередком розвитку сакрального мистецтва. Крім суто венеційських майстрів, тут навчалися нових навиків східного стилю інші відомі митці, які залишили у своїй творчості значну кількість зображень Богородиці. Найважливіша колекція венеційського живопису знаходиться у Галереї Академії Венеції (Le Gallerie dell'Accademia di Venezia). Архітектурний комплекс, в якому розташована галерея, складається з декількох історичних будівель: церкви Santa Maria della Carità, монастиря та приміщення Scuola Grande. У галереях розміщено 37 залів (13 - на першому поверсі, 24 - на другому), які репрезентують виставковий маршрут, що веде від живопису XIV до XVIII ст. ${ }^{16}$

На особливу увагу заслуговують твори основоположника відомої венеційської живописної школи Паоло Венеціано (XIV ст.) ${ }^{17}$. У творчості маляра спостерігається цікаве переплетення впливів візантійського та готичного мистецтва. Визначні полотна митця із зображенням Богоматері зберігаються у відомих музеях світу (найчастіші сюжети - «Мадонна з Немовлям на троні», «Коронація Пречистої Діви»). У венеційській галереї зберігаються такі його твори: «Мадонна з немовлям на троні» 18 , «Мадонна 3 Дитям на троні» ${ }^{19}$, поліптих Санта-К'яра 3 центральною композицією «Коронації Богородиці»20. Інші непересічні полотна цього живописця із зображенням Пречистої Діви Марії можна побачити у храмах Венеції - «Мадонна 3 немовлям на троні, дож Франческо Дандоло, Франциск Ассизький і св. Єлисавета Угорська» (церква Santa Maria Gloriosa dei Frari)21, «Мадонна з Дитям» (церква San Pantalon) ${ }^{22}$ тощо.

Значний внесок у розвиток венеційського мистецтва належить також живописцю Джованні Белліні (XV - поч. XVI ст.)23. Його твори із зображенням Мадонни 3

\footnotetext{
14 Domenico Tintoretto, Venezia implora la Vergine di intercedere con Cristo per far cessare la peste, 1631. Venezia, chiesa di San Francesco della Vigna. URL: https://www.jerusalem-lospazioltre.it/tintoretto-allascuola-grande-san-marco-larte-la-cura/domenico-tintoretto-venezia-implora-la-vergine-di-intercederecon-cristo-per-far-cessare-la-peste-1631-venezia-chiesa-di-san-francesco-della-vigna/

15 Doge Niccolo' da Ponte davanti alla Vergine in gloria. URL: http://www.culturaitalia.it/opencms/viewItem.jsp?language=it\&case=\&id=oai\%3Ascalarchives.com $\% 3$ A0113506

16 Collezione. URL: http://www.gallerieaccademia.it/collezione

17 Pedrocco F. Paolo Veneziano, Milano, 2003; Boskovits M. Paolo Veneziano: riflessioni sul percorso (parte I) // Arte cristiana. 2009. № 97. P. 81-90.

18 Madonna con Bambino. Paolo Veneziano. URL: http://www.gallerieaccademia.it/node/2002

19 Madonna col Bambino in trono e due committenti. Paolo Veneziano URL: http://www.gallerieaccademia.it/madonna-col-bambino-trono-e-due-committenti

20 Polittico dell'incoronazione Della Vergine. Paolo Veneziano. URL: http://www.gallerieaccademia.it/polittico-dellincoronazione-della-vergine

${ }^{21}$ Madonna con Bambino, Santi e il Doge. URL: https://www.basilicadeifrari.it/opere/madonna-conbambino-san-francesco-e-santa-elisabetta-presentano-il-doge-e-la-dogaressa/

${ }^{22}$ Le opere. URL: https://www.sanpantalon.it/arte/

${ }^{23}$ Blass-Simmen B. Giovanni Bellini: Landscapes of Faith in Renaissance Venice. // Renaissance Quarterly. 2019. Vol. 72. № 4. P. 1436-1437; Mazzotta A. In his father's workshop: Giovanni Bellini's paintings
} 
Дитям також зберігаються у багатьох музеях світу. Натомість у Венеції цінна збірка розміщена у «Галереї Академії» та «Museo Correr», а також у храмах - «Мадонна 3 Дитям» (chiesa della Madonna dell'Orto), «Мадонна з Дитям, святими та донатором» (chiesa di San Francesco della Vigna)24. Також у Галереї зберігається твір венеційського майстра цього ж періоду Якопо Негретті (Пальми Старшого, Palma Vecchio) «Небовзяття Пречистої Діви» 25 .

Стилістику венеційської школи кінця XV - XVI ст. яскраво представляють праці визначного живописця Тіціана Вечелліо. Неможливо оминути його відоме полотно «Небовзяття Богородиці» у головному вівтарі храму Santa Maria Gloriosa dei Frari, a також полотна із зображенням Богоматері, що зберігаються у вже згаданій «Галереї Академії» Венеції, зокрема «Мадонна з Дитям», «Введення у храм Пречистої Діви» та «Пієта» 26 . Непересічні роботи належать також венеційському митцю Доменіко Тінторетто (XVI - перша пол. XVII ст.), сину відомого майстра релігійного живопису Якопо Тінторетто (XVI ст.) Полотна та поховання живописця знаходяться у Chiesa della Madonna dell'Orto. До речі, цей храм також відомий у Венеції з огляду на чудотворну статую Богородиці ${ }^{27}$. Одна з найцікавіших робіт Д. Тінторетто - вже згадане полотно, де зображено персоніфіковану Венецію, яка навколішки просить Богородицю про молитовне заступництво у справі зупинення епідемії чуми у Венеції у 1631 p. 28

Серед робіт митця Паоло Веронезе (XVI ст.) необхідно виокремити: «Небовзяття Пречистої Діви» (колись полотно було у храмі Santa Maria Maggiore, але з 1812 p. зберігається у Галереї Академії) 29 , «Коронація Пречистої Діви» (Chiesa di San Sebastiano), «Мадонна з Дитям і святими» (Chiesa di San Sebastiano) й ін. Полотна із зображенням Богоматері іншого визначного венеційського живописця Джакомо Пальма Молодшого (Giacomo Palma il Giovane, XVI - початок XVII ст.), можна побачити у храмі San Zaccaria («La Vergine che porge il Bambino a San Francesco») ${ }^{30}$. Варто також згадати про полотно Джорджо Ладзаріні «Непорочна» (XVIII ст.) («Immacolata», Giorgio Lazzarini, Chiesa San Francesco della Vigna) ${ }^{31}$.

Крім цього, у площині переплетення різних мистецьких стилів, цікавими для дослідників є праці майстрів грецького походження, які певний час перебували у Венеції. Зокрема, відомий художник Ель-Греко 32 (Доменікос Теотокопулос), котрий

for the Scuola di S. Giovanni Evangelista, Venice // Burlington Magazine. 2018. Vol. 160. № 1381. P. 283290.

${ }^{24}$ Madonna col Bambino Benedicente. Giovanni Bellini. URL: http://www.gallerieaccademia.it/madonna-col-bambino-benedicente

25 Assunzione della Vergine. Jacopo Negretti Betto Palma Il Vecchio. URL: http://www.gallerieaccademia.it/assunzione-della-vergine

${ }^{26}$ Madonna col Bambino. Tiziano Vecellio. URL: http://www.gallerieaccademia.it/madonna-colbambino-1

${ }^{27}$ Chiesa della Madonna dell'orto. URL: http://www.arte.it/guida-arte/venezia/davedere/chiesa/chiesa-della-madonna-dell-orto-954

28 Domenico Tintoretto. Venezia implora la Vergine di intercedere con Cristo per far cessare la peste.

${ }^{29}$ Assunzione della Vergine. Paolo Caliari Detto Paolo Veronese. URL: http://www.gallerieaccademia.it/assunzione-della-vergine-0

${ }^{30}$ Chiesa San Francesco della Vigna - Presbiterio e coro. URL: https://www.isevenezia.it/it/default.aspx?PAGINA=867\&id=4\&foto_id=52

31 Chiesa San Francesco della Vigna - Presbiterio e coro...

32 Mare E.A. El Greco's Italian Paintings (1560-76) Based on Bible Texts // Acta Theologica. 2009. № 29 (1). P. 61-80; Marias F. Miles Christi, once again: El Greco and His Clients in Venice // Goya. 2017. № 358. P. 30-45. 
завжди підписував свої твори грецькою мовою, акцентуючи на своєму критському походженні з метою зберегти власну культурну ідентичність у мультикультурному середовищі33. У творчому доробку митця також $є$ велика кількість зображень Богородиці. Художник певний період перебував у Венеції для ознайомлення з особливостями венеційського мистецтва, зокрема маньєризму та знайомства зі східним стилем, а згодом врешті виробив власний особливий стиль зображень сакральної тематики ${ }^{34}$. В експозиції венеційського музею «Museo Correr» зберігається його картина «Sant'Agostino» (1567-1570 pp.), на якій вгорі також є чудове зображення Богородиці з Дитям на руках 35 .

Також у Венеції можна побачити твори митців грецького походження, єдині збережені роботи яких зберігаються саме тут. Зокрема, в експозиції вже згаданого «Museo Correr» представлено підписаний твір маловідомого грецького митця Джованні Перменіате (Giovanni Permeniate) із зображенням Богоматері «Madonna in trono tra Santi Agostino e Battista». Це полотно часто привертало увагу мистецтвознавців та істориків, з огляду на дотичність до історії Венеції ${ }^{36}$. Іншим цікавим взірцем є робота живописця грецького походження, що певний час перебував у Венеції, Антоніо да Негропонте (Antonio da Negroponte) «Мадонна з Дитям на троні» («Madonna in trono col Bambino», chiesa di S. Francesco delle Vigne, XV ст.) ${ }^{37}$.

На особливу увагу дослідників заслуговує також колекція Галереї та музею «Fondazione Querini Stampalia», де також зберігаються полотна із зображенням Богоматері відомих представників живописної венеційської школи (зокрема, Якопо Негретті (Пальми Старшого) - «Мадонна з двома святими, св. Франциском і св. Петром» 1527 р., 3 його майстерні - «Мадонна зі св.Катериною, св. Франциском, св. Йоаном Хрестителем і св. Миколаєм» приблизно 1528 р.; полотна Джана Беттіно Чіньяролі - «Мадонна з Дитям», приблизно 1735 р.; Донато і Катаріно «Коронація Пречистої Діви Марії» 1382 р.; Бернардо Строцці «Мадонна 3 Дитям», приблизно 1635-38 рр.; Пальми Молодшого - «Небовзяття Богородиці»; а також твори Лоренцо ді Креді, Ніколо Бамбіні, Джованні Белліні й ін.) ${ }^{38}$.

Ще одне доволі відоме у світовому вимірі зображення Богородиці, пов'язане 3 Венецією, - «La Madonnina» італійського художника Роберто Ферруцці (Roberto Ferruzzi), що прожив частину свого життя у Венеції. Саме це полотно здобуло перемогу на II Бієннале Венеції у 1897 р. Зображення відоме під різними назвами: на початку автор титулував твір як «Материнство», а згодом полотну надали додаткові назви - «Madonna del Riposo», «Madonna delle Vie», «Madonna della Tenerezza» й ін. Мініатюрна капличка з копією цього знаменитого зображення знаходиться на каналі Сант Еразмо венеційської лагуни ${ }^{39}$.

Особливо актуальною темою для окремого дослідження є сакральна скульпту-

\footnotetext{
${ }^{33}$ Casper A. Greeks abroad: (as)signing artistic identity in early modern Europe. // Renaissance Studies. 2014. Vol. 28, Issue 3. P. 356-376.

34 Puppi L. Il Greco giovane e altri pittori «Madonneri» di maniera italiana a Venezia nella seconda metà del Cinquecento // Prospettive. 1963. № 26/27. P. 25-46.

35 Domenico Theotokopoulos detto

http://www.cassiciaco.it/navigazione/iconografia/pittori/cinquecento/el_greco/el_greco_correr.html

36 Bianco Fiorin, Marisa. Giovanni Permeniate... P. 86.

37 Pittore Antonio da Negroponte. URL: https://www.frammentiarte.it/2014/antonio-da-negroponte/

${ }^{38}$ Catalogo. URL: http://www.querinistampalia.org/ita/museo/antiche_collezioni/disegni.php

${ }^{39}$ Capitello su «bricola» nel Canale di Sant'Erasmo/Canale di Tresso. URL: https://www.conoscerevenezia.it/?p=39581\#
} 
ра Венеції 40 . На фасадах венеційських будинків часто можна побачити статуї Ісуса Христа, святих, хреста, ангелів, євхаристійних монограм і велику кількість статуй і барельєфів Богородиці. Щодо композиційних сюжетів та їхньої кількості, 69 скульптур - це «Богородиця», 1 - «Богоматір скорботна», 155 - «Богородиця з Дитям», 1- «Богородиця Вервиці», 16 - «Богородиця милосердя», 3 - «Богородиця Непорочна», 1 - «Madonna Sacro Cuore»41. Один із знаменитих барельєфів - «Madonna dei gondolieri» (розташування - Ponte della Paglia). Також доволі відома у Венеції вже згадана чудотворна скульптура Богородиці «Madonna dell’Orto». Увагу дослідників привертає також статуя Богородиці Непорочної XVIII ст. на фасаді палацу Fondamenta Rezzonico ${ }^{42}$.

Інший важливий вимір Богородичної тематики у сакральному мистецтві Венеції та островів Венеційської лагуни, який яскраво репрезентує візантійські мистецькі впливи, є мозаїки базилік. Зокрема, детальну увагу дослідників упродовж століть привертають мозаїки собору Сан Марко у Венеції. У них представлені ключові моменти біблійної історії. Відповідно, зображення Богородиці відіграють важливу роль. Дослідженню цього собору та його мозаїк науковці присвятили велику кількість праць. Зокрема, на зовнішньому фасаді базиліки $\epsilon$ цікаве зображення «Madonna di Broglio».43 Цікаву історію цієї мозаїки подає італійська книга XVIII ст., де згадано про купця, що врятувався від небезпеки у далекій дорозі молитвою до Богородиці44. Натомість всередині базиліки варто виокремити мозаїку Богородиці Оранти XIII ст. у центральному нефі, а також у куполі пресвітерію, де зображено Богоматір, пророків, Ісайю, Давида.

Особливу увагу привертає настінна мозаїка із золотим фоном «Богородиця Оранта» XII ст. базиліки о. Мурано (Basilica dei Santi Maria e Donato). Мозаїка, виконана у візантійському стилі, знаходиться в апсидальному просторі, над головним вівтарем. Це зображення дуже схоже на Богородицю із церкви сусіднього острова Торчелло (Basilica di Santa Maria Assunta e Chiesa di Santa Fosca, Torcello). Однак у цьому випадку - Пречиста Діва Марія з Дитям на руках, тобто іконографічна композиція Одигітрії. Мозаїки з о. Мурано репрезентують професійні досягнення венеційських майстрів, які добре навчилися візантійського стилю першої половини XII ст. Стиль насправді $є$ таким же як у візантійських майстрів, які працювали у базиліці Сан-Марко у Венеції (наприклад, у зображенні Богородиці Оранти у куполі «Вознесіння» і в частинах базиліки Торчелло, особливо люнет, що датується останньою чвертю XII ст.). Однак лінійність драпірування та стрункі силуети виразно відмежовують ці мозаїки від робіт візантійських майстрів, які працювали в апсиді базиліки Торчелло, остаточно демонструючи самостійність і художню специфіку, характерну для нового покоління венеціанського мозаїчного мистецтва дру-

\footnotetext{
${ }^{40}$ Mason, Mara. Venezia O Costantinopoli? Sulla scultura bizantina a Venezia e nell'entroterra veneto e ancora sulla Beata Vergine della Cintura di Costantinopoli di Treviso // Saggi e Memorie di storia dell'arte. 2012. Vol. 36. P. 7-56.

41 Mappa delle sculture devozionali pubblicamente visibili a Venezia e nelle isole del suo estuario. URL: https://www.conoscerevenezia.it/?p=5164; Madonna coronata col Bambino, bassorilievo di Campo San Polo. URL: https://www.conoscerevenezia.it/?p=16462

${ }^{42}$ Statua della Madonna Immacolata di Fondamenta Rezzonico. URL: https://www.conoscerevenezia.it/?p=15421

43 Basilica di San Marco (facciata esterna verso la Piazzetta) - Madonna di Broglio. URL: https://www.conoscerevenezia.it/?p=33987

44 Cornaro F. Venezia favorita da Maria... P. 117-118.
} 
гої половини XII ст. 45

Особливо цікавою для дослідників $є$ історія та музей о. Торчелло. У музеї представлено колекцію візантійських ікон XIV-XV ст., історію зниклої частини Торчелло, зруйнованих церков (зокрема храму св. Антонія) ${ }^{46}$. Історія, архітектура, археологія, дослідження мозаїк і фресок церков острова є доволі актуальною темою досліджень. Зокрема, цікаві порівняльно-аналітичні розвідки присвячені особливостям мозаїк адріатичного регіону і мистецьких зв’язків, т. зв. «мистецького трикутника» Венеція-Візантія-Равенна 47 , а також Венеції, о. Торчелло та Істрії48. Яскравим взірцем є мозаїка базиліки, де Богородиця у темно-синьому мафорії зображена на золотому тлі (робота візантійського майстра другої половини XII ст.), а внизу апостоли. Комплекс мозаїк цієї базиліки належить до одного з найважливіших циклів мозаїчного мистецтва на півночі Італії, разом з мозаїками відомої базиліки Santa Maria Maggiore у Римі ${ }^{49}$.

Таким чином, зображення Богородиці у релігійному живописі, іконописі, сакральній скульптурі, мозаїках Венеції репрезентує сучасним дослідникам багатий матеріал для аналітики на перетині історії, мистецтвознавства, архітектури, музеєзнавства, культурної спадщини, теології тощо. Історія міста пронизана цікавими свідченнями особливої набожності до Пречистої Діви Марії, що яскраво відображено у венеційському мистецтві. Як свідчать джерела, у часі частих у Венеції епідемій чи інших загрозливих ситуацій венеціанці просили заступництва Богородиці перед відомими чудотворними іконами у храмах міста. Відповідно, детальне дослідження історії цих зображень відкриває особливі сторінки з життя міста в історичній перспективі. Грунтовне вивчення полотен із зображенням Богородиці авторства визначних представників венеційської школи живопису репрезентує багату палітру специфіки розвитку мистецьких стилів. Крім цього, цікавою тематикою для актуальних досліджень $є$ порівняльний аналіз мозаїк базилік Сан Марко, о. Торчелло, о. Мурано й інших відомих церков (до прикладу, Оранти у Софійському соборі Києва, мозаїки Богородиці з Ая-Софія у Стамбулі й інших відомих візантійських храмів того часу).

\section{REFERENCES}

Bianco Fiorin, Marisa (1981). Giovanni Permeniate Pittore greco a Venezia e una tavola del Museo Nazionale di Ravenna. In Bollettino d'Arte, Serie 6 (Vol. 11, pp. 85-88). Roma: La libreria dello Stato.

Blass-Simmen, B. (2019). Giovanni Bellini: Landscapes of Faith in Renaissance Venice. Renaissance Quarterly. Vol. 72. No 4, 1436-1437.

Boskovits, M. (2009). Paolo Veneziano: riflessioni sul percorso (parte I). Arte cristiana, 97, 81-90.

Caselli, L. (2002). Mosaici e sculture veneto-bizantine del Museo provinciale di Torcello. Stato degli studi

\footnotetext{
45 Vergine Orante Della Basilica dei SS. Maria e Donato. URL: http://www.iconedelveneto.it/basilica-deisanti-maria-donato/

${ }^{46}$ Museo di Torcello. URL: https://museotorcello.servizimetropolitani.ve.it/il-museo/; Caselli L. Mosaici e sculture veneto-bizantine del Museo provinciale di Torcello. Stato degli studi e problemi // Progetto Restauro. 2002. № 21. P. 22-31.

${ }^{47}$ Rizzardi, Clementina. Mosaici altoadriatici: il rapporto artistico Venezia-Bisanzio-Ravenna in età medievale. Ravenna: Edizioni del Girasole, 1985; Penni, Emanuela. Dante e i mosaici di Torcello. Nel triangolo magico Bisanzio-Ravenna-Venezia. Ravenna: Edizione del Girasole, 2019.

${ }^{48}$ Caselli, Letizia. Torcello, Venezia e l'Istria. Di alcune interazioni e sfere di influenza nella cultura storico-artistica dell'alto Adriatico tra Tarda antichità e Altomedioevo. // Histria Terra (Trieste). 2009. № 10. P. 7-35.

${ }^{49}$ Nuovi gadget per la basilica di Santa Maria Assunta. URL: https://blog.sadesign.it/basilica-di-santamaria-assunta/
} 
e problem. Progetto Restauro, 21, 22-31.

Caselli, L. (2009). Torcello, Venezia e l'Istria.Di alcune interazioni e sfere di influenza nella cultura storico-artistica dell'alto Adriatico tra Tarda antichità e Altomedioevo. Histria Terra, 10, 7-35.

Casper, A. (2014). Greeks abroad: (as)signing artistic identity in early modern Europe. Renaissance Studies. Vol. 28, Issue 3, 356-376.

Cornaro, Flaminio (1758). Venezia favorita da Maria. Relazione delle imagini miracolose di Maria conservate in Venezia. Padova: Giov. Manfre.

Corner, Flaminio (1761). Notizie storiche delle apparizioni, e delle immagini più celebri di Maria Vergine Santissima nella città e dominio di Venezia. Tratte da Documenti, Tradizioni, ed antichi libri delle Chiese nelle quali esse Immagini son venerate. Venezia: Presso Antonio Zatta.

De Fiores, S. (2010). La Madonna in Michelangelo. Libreria Editrice Vaticana.

Francia, V. (2004). Splendore di bellezza. L'íconografia dell'Immacolata Concezione nella pittura rinascimentale italiana. Città del Vaticano.

Mason, Mara (2012). Venezia O Costantinopoli? Sulla scultura bizantina a Venezia e nell'entroterra veneto e ancora sulla Beata Vergine della Cintura di Costantinopoli di Treviso. Saggi e Memorie di storia dell'arte, (36), 7-56.

Mare, E.A. (2009). El Greco's Italian Paintings (1560-76) Based on Bible Texts. Acta Theologica, 29 (1), 61-80.

Marias, F. (2017). Miles Christi, once again: El Greco and His Clients in Venice. Goya, (358), 30-45.

Mazzotta, A. (2018). In his father's workshop: Giovanni Bellini's paintings for the Scuola di S. Giovanni Evangelista, Venice. Burlington Magazine, CLX, 283-290.

Pedrocco, F. (2003). Paolo Veneziano, Milano, 2003.

Penni, E. (2019). Dante e i mosaici di Torcello. Nel triangolo magico Bisanzio-Ravenna-Venezia. Ravenna: Edizione del Girasole.

Puppi, L. (1963). Il Greco giovane e altri pittori «Madonneri» di maniera italiana a Venezia nella seconda metà del Cinquecento. Prospettive, 26/27, 25-46.

Rizzardi, C. (1985). Mosaici altoadriatici: il rapporto artistico Venezia-Bisanzio-Ravenna in età medievale.Ravenna: Edizioni del Girasole.

Sadesign (2016, 24 giugno). Nuovi gadget per la basilica di Santa Maria Assunta. Il blog di Sadesign.it. Creative Merchandising. Retrieved from https://blog.sadesign.it/basilica-di-santa-maria-assunta/

Salvador-González, J.M. (2013). The Iconography of the Coronation of the Virgin In Late Medieval Italian Painting. A Case Study. Eikón / Imago, 3 (1), 1-48.

Tridello, Mattio (2020). Santa Maria della Salute a Venezia. Retrieved from https://www.progettostoriadellarte.it/2020/05/26/santa-maria-della-salute-a-venezia/

Venezia (1985). Touring club italiano. Touring Editore.

Verdon, T. (2001). L'arte sacra in Italia. L'immaginazione religiosa dal paleocristiano al modern. Milano.

Verdon, T. (2004). Maria nell'arte europea. Milano.

\section{Iryna Hnidyk}

(Lviv Polytechnic National University, Lviv, Ukraine)

e-mail: iryna.i.hnidyk@lpnu.ua

ORCID: https://orcid.org/0000-0001-7560-3365

\section{Images of Mother of God in Sacred Art and Museum Collections in Venice}

The peculiarities of the image of Mother of God in religious painting, sacred sculpture, and mosaics of Venice are analyzed in the paper. The basis for the work is research and information resources in Italian and English. An interesting source for the work is Italian ancient books, representing the important role of the Blessed Virgin Mary veneration in the Venetian space in historical retrospection. The specificity of this theme is especially relevant in the field of interdisciplinary research - history, art history, cultural heritage, Mariology, etc.

The analysis of key compositional scenes of the image of Mother of God in the artistic heritage of Venice is carried out on the example of paintings by prominent representatives of the famous Venetian art school (Paolo Veneziano, Giovanni Bellini, Titian, Jacopo Palma the Elder (Negretti), Jacopo Tintoretto, Paolo Veronese, Domenico Tintoretto, Jacopo Palma the Younger), as well as some artists of Greek origin, who for some time improved their profes- 
sional skills in Venice (El Greco (Domenikos Theotokopoulos), Giovanni Permeniate, Antonio da Negroponte). The compositional schemes of the Blessed Virgin Mary image in the sculptural art of Venice are also schematically analyzed.

An important role in the study belongs to the review of vivid examples of the image of the Blessed Virgin Mary in the collections of the Venetian museums (Gallerie dell'Accademia di Venezia, the Fondazione Querini Stampalia Gallery, and Museum, Museo Correr, etc.).

A special place in the work is given to the review of the specifics of the mosaics of the Basilica di San Marco and the basilicas of the islands of the Venetian lagoon (Murano and Torcello islands) in a comparative context. The prospect of further research of these mosaics in the sense of deeper comparison and analysis of stylistic features of outstanding samples of Mother of God mosaic image in well-known Italian and Byzantine temples is offered.

Keywords: Mother of God, sacred art, Venice, museums, mosaics, religious painting, icon 